\title{
Rethinking the Heritage Value from Different Perspectives, Case Study in Yogyakarta
}

\author{
Johannes Parlindungan Siregar ${ }^{1 \odot}$, Wara Indira Rukmi $2 \odot$ \\ ${ }^{1}$ Department of Regional and Urban Planning, Faculty of Engineering, Universitas Brawijaya, Indonesia. (Principal contact for \\ editorial correspondence), Email: johannes@ub.ac.id \\ ${ }^{2}$ Department of Regional and Urban Planning, Faculty of Engineering, Universitas Brawijaya, Indonesia. Email: \\ wara_indira@ub.ac.id
}

\begin{abstract} Purpose

Today heritage is of strategic importance not only because of its historical value, but also due to the capacity to sustain traditional philosophy. A problem arose in association with the overcommercialisation of heritage that led to a question of how the citizens react to the problem and the emerging values. The purpose of this study is to explore the relationship between heritage conservation practices conducted by the government and local people.
\end{abstract}

Design/Methodology/Approach

This study used qualitative analysis to investigate official documents and newspapers. In-depth interviews were used to elaborate citizens' perception about heritage values.

Findings

There were connection and disconnection between the implementation of heritage conservation policy and citizens' opinions about conservation practices. The connection should be maintained to anticipate the change of meanings and overcome problems stemmed from heritage tourism and the uncontrolled urban development.

\section{Research Limitations/Implications}

This study bridged a possibility of evaluating the impact of urban development on heritage value by assessing perspectives from different social actors. It was evidenced that the official and unofficial values of heritage are differently recognised. However, this study had a limitation in terms of the social group involved in interviews. The analytical framework of this research needs to be developed incorporating quantitative analysis with a survey of particular population in Yogyakarta. This kind of study is essential to discovering how the population reacts to urban development and heritage sites.

\section{Social/Practical Implications}

The government should not dominate the practice of heritage conservation. It is essential to maintain the cultural authenticity of heritage by involving general public in monitoring urban development surrounding heritage sites.

\section{Originality/Value}

This study provides a framework for integrating different perspectives to better recognise and manage heritage sites and the overall urban landscape. This framework can be used as a foundation for evaluating heritage impact relating to societal changes and the dynamics of urban development.

Keywords: Heritage conservation, official heritage, unofficial heritage, traditional philosophy, Yogyakarta 


\section{INTRODUCTION}

Yogyakarta is the capital of Daerah Istimewa Yogyakarta Province, located in the Central Java region, Indonesia. This city is a tourist destination not only for its heritage, but also for providing access to two other World Heritage sites-Borobudur and Prambanan temples. The significance of Yogyakarta urban centre is evidenced as it is included in the tentative lists of world heritage sites for its traditional urban form (UNESCO, 2017).

The current approach of Heritage Conservation (HC) demonstrates the domination of national and local governments by using heritage regulations and policies. Indonesia heritage law concerns the physicality of historical objects, i.e., statues, temples, buildings, and sites (The Republic of Indonesia, 2010). In addition, the law also mandates the use of heritage in economy and education reflecting the implementation of sustainable development principles in $\mathrm{HC}$ as suggested by World Heritage Committee (2015). The local government implements sustainable development agenda to encourage local initiatives in strengthening local economy and public well-being through HC.

Despite some advantages of HC, the implementation of this policy is problematic due to two reasons. Firstly, the current HC regulation generally recognises buildings and monuments created before 1945 , the year of Indonesia's Proclamation of Independence, which represent the memory of war. In fact, heritage in Yogyakarta is not only associated with collective memories about the war, but also with the tradition of local people. Secondly, the use of heritage as economic resource tends to give negative implications for HC. The over-commercialism of heritage in the tourism industry leads to a shift from cultural value to commercial value (Shepherd, 2002). Loulanski (2006) conforms this idea by suggesting that heritage tourism has a 'parasitical effect' on cultural value. This problem has been evidenced in Yogyakarta. Mass media have reported facts and public opinions regarding this issue. The demolition of historic buildings and the growth of modern commercial facilities have become a threat to the existence of heritage (Kusumaputra, 2010). As a result, the image of Yogyakarta as a historic city tends to be replaced by commercialism (Alexander, 2015). These issues motivated this study to understand how the current HC approach can fit into conservation practice in Yogyakarta and connect with the everyday values of local citizens. Hence, this study contributed to expanding the understanding of this complexity that can be used to develop a better $\mathrm{HC}$ policy as well as the knowledge of $\mathrm{HC}$ as an academic discourse in Indonesia.

This study aimed at exploring the connection between HC practices on the basis of paradigms held by government and local people. The practice of $\mathrm{HC}$ was investigated using the notions of 'official heritage' and 'unofficial heritage' referring to the two variations of conservation practices and heritage values (Harrison, 2013). The first one corresponds to the practice of $\mathrm{HC}$ on the basis of professional practices 
and governmental policy. The second one represents HC practices and paradigm of ordinary people through the everyday meanings of heritage perceived by general public as suggested by Byrne (2008) and Malpas (2008).

\section{THEORETICAL RATIONALE}

The discourse of official and unofficial heritage begins with the concept of value. Fredheim and Khalaf (2016) argue that the value or 'significance' is the main reason for heritage conservation. The international conventions of heritage have contributed to the notion of heritage value (ICOMOS, 2004). Athens Charter in 1931 suggests aesthetic and history as principal values of a monument. In addition, Nara Document introduces the concept of 'authenticity' and 'cultural context' as the principal aspects pertaining to heritage value. This document allows every society to perform different ways in considering heritage value or authenticity relevant to their societal context.

The value of heritage is not an absolute idea. In contrast, it is an assemblage of various value categories from different social agents. Regarding this, Fredheim and Khalaf (2016) suggest the values interpreted by 'experts' and 'non experts', which have different perspectives in recognising heritage values and determining appropriate conservation actions. As asserted by Tweed and Sutherland (2007), the recognition of heritage can be performed through institutional process and everyday appropriation of general public. This situation reflects the presence of two perspectives in the recognition of heritage values, which involves formal institutions as the representative
of 'official heritage' and general public as the representative of 'unofficial heritage'.

The official heritage represents the approach of formal agencies, i.e. the government, to recognising heritage value and determining appropriate HC policy. World Heritage Committee (2015) encourages the states parties to comply with sustainable development principles in HC. Unlike the official heritage, the unofficial heritage resembles a bottom-up approach. Heritage, particularly the one located in urban space, has a constant interaction with observers. The interaction between observer and the environment allows human perception to evoke meanings (Juodinyte-Kuznetsova, 2011). As a part of physical site, heritage can encourage observers to experience the place and capture particular meanings, emotions or thoughts (Jokilehto, 2006). In this regard, the heritage value is produced from people's personal and shared experiences in a historic area (Schorch, 2014). Some scholars have incorporated public's perceptions in heritage study. Su (2018) investigated the notion of heritage authenticity from the perspective of locals in Lijiang, China. The locals tended to internalise the value of intangible heritage through their daily social and cultural practices. Herliana, Hanan, and Kusuma (2019) supported Su's finding by asserting that local people had particular attachment to their settlement 
shaped by daily experiences associating with history, social live and tradition. This phenomenon was typical in Yogyakarta traditional settlement. In the case of urban landscape, Najd et al. (2015) demonstrated the approach of 'visual preference' in evaluating heritage social value. Their study made a foundation for connecting heritage value to physical situation around the heritage sites. These studies suggest that the non-expert's perspective should not be ignored in assessing heritage value. Through this way, heritage can be deeply rooted in the society.

A problem exists when there is no good connection between the two approaches. The study found that the official value of heritage is perceived differently by general public due to the over-developed environment. This situation reflects failures to control urban development around the heritage sites and recognise the everyday meanings of heritage. There is no enough knowledge about how the official and unofficial approaches of HC can collaborate in constructing heritage value. Nevertheless, the study in Yogyakarta demonstrates a potential for integrating the two approaches.

\section{YOGYAKARTA AS A MIX OF TRADITIONAL AND COLONIAL CITY}

The city of Yogyakarta is located in the southern area of Central Java (see Figure 1). The currently reigning Sultan administrates the province as a governor. The province is comprised of four regencies (Bantul, Gunungkidul, Sleman, and Kulon Progo) and one municipality (Yogyakarta). The municipality, as the setting of this study, corresponds to the past embryo and the current urban area of the province.

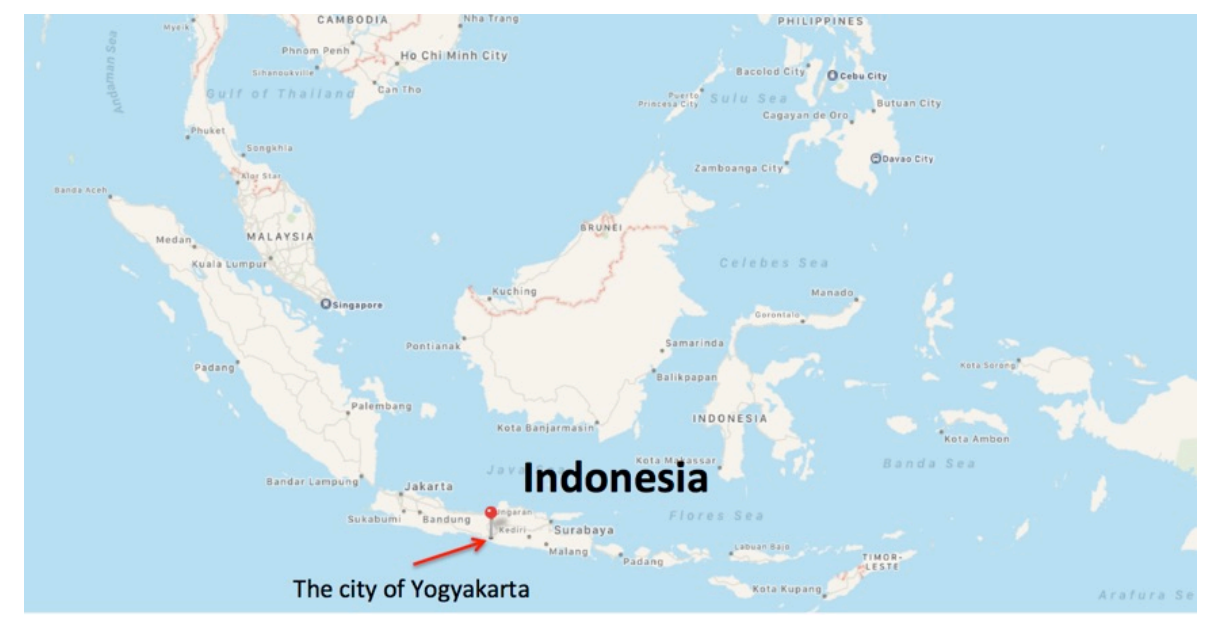

Figure 1. The location of Yogyakarta on Indonesia map. (Google Maps, 2019)

The city of Yogyakarta was founded in 1755 as the result of Gayanti treaty initiated by the colonial authority (Luthfi et al., 2014). The first Sultan of Yogyakarta designed the city centre using two traditional philosophies: Philosophical Axis and Catursagatra (Suryanto et al., 2015), as depicted in Figure 2. Traditional philosophy is the wisdom of local culture deeply rooted in the society. The traditional urban fabrics were built in the 1700s. Handinoto (2015) suggests that the first Sultan 
of Yogyakarta was the primary initiator of the city design. The descriptions of Yogyakarta traditional urban fabrics are as follows.

- Philosophical axis takes the form of an axis connecting the South Ocean to the north and Mount Merapi to the South. This philosophy has three elements, i.e., Panggung Krapyak monument, Kraton (the palace complex), and Tugu monument. Panggung Krapyak monument is a 10-metre tall building with a shape similar to a truncated pyramid. Tugu monument is a column of 15 metres tall located at a junction to the north of Kraton complex. Suryanto et al. (2015) suggest that the Philosophical Axis symbolises a philosophy called Sangkan Paraning Dumadi connoting a wisdom about God as the origin of life. People should always remember that anything comes from God and will return to God.

- Catursagatra is a compound comprising four contiguous urban objects, i.e., Kraton, the Alun-Alun Lor or the northern square, the Great Mosque, and Beringharjo market. This traditional philosophy connotes a harmony between micro and macro cosmoses manifested through the quality of leadership, spirituality, economy, and culture as the integral elements of Society. Karsono and Wahid (2008) argue that Kraton, Alun-Alun square, Mosque, and Beringharjo market symbolise the social aspect of human life through which a human becomes a member of society and develops wisdom.

Figure 2. The map shows the locations of traditional urban fabrics representing Catursagatra and Philosophical Axis. (Google Maps, 2020 and photograph by the first author, 2019).

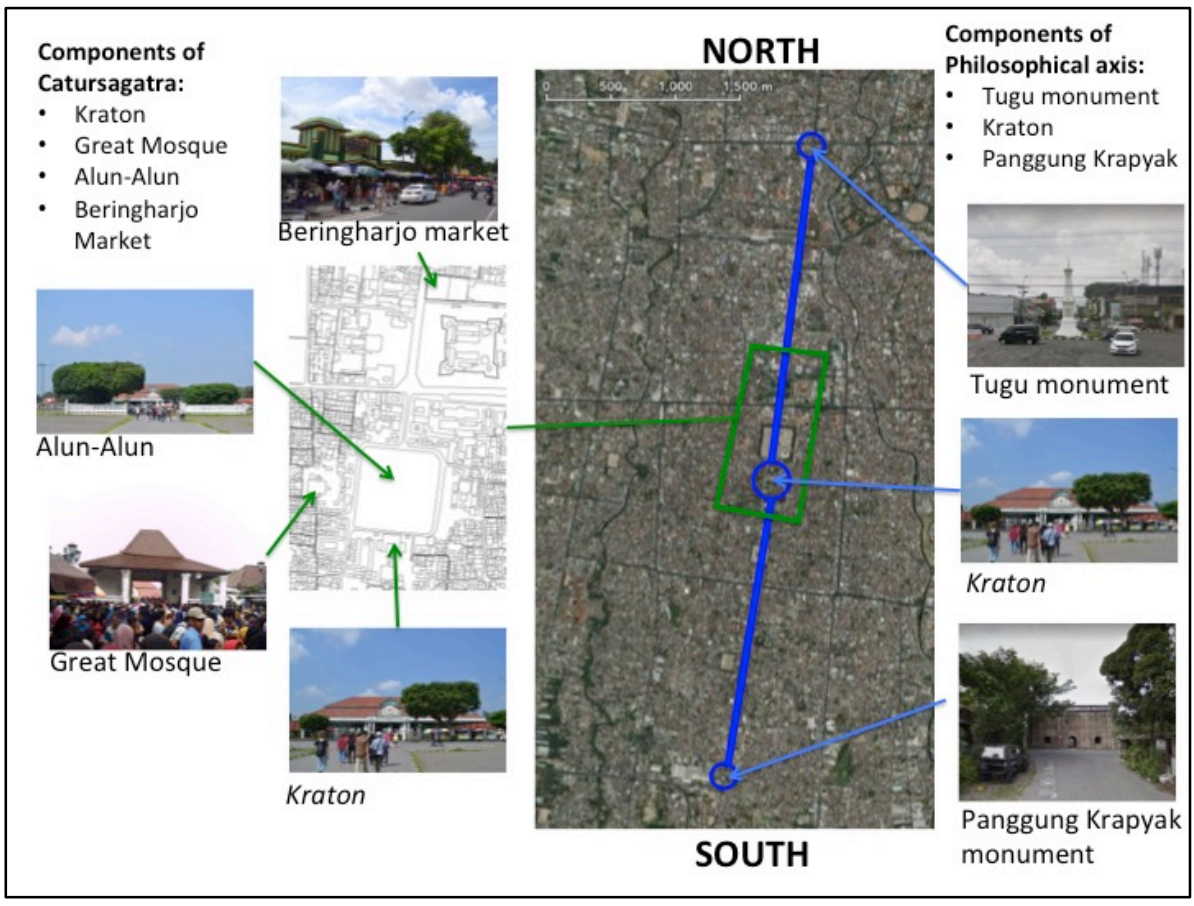

In addition to its traditional philosophy, Yogyakarta also has colonial structures reflecting the influence of Dutch colonisation. The colonials had settled in the Central Java territory since the foundation of Yogyakarta in 1755. The Dutch government strengthened its political power by constructing Vredeburg fort to the north of Kraton in 1765 
and Assistant Residence office in 1824 (Karsono \& Wahid, 2008). Yunus (1991) suggests that in the early $20^{\text {th }}$ century, Dutch authority fostered economic development and industrialisation by constructing railway stations, markets, and offices. In the field of architecture, the Dutch architects introduced particular style called Indische architecture to Yogyakarta. This architectural style was a combination of European and Indonesian building traditions (Veenendaal \& Knaap, 2015).

\section{METHODOLOGY}

The location of this study was the urban centre of Yogyakarta, which constitutes a historic area surrounding the philosophical axis and Catursagatra. The area was also the centre of governmental dan economic businesses in the city. This study used multiple data sources to maintain data credibility as suggested by Ritchie, Lewis, Nicholls, \& Ormston (2013). The triangulation was achieved by adding data sources in terms of documents and research participants. The analyses were made in three stages:

- First stage: the analysis of official heritage. This analysis focused on conservation practices regulated by the Yogyakarta government and debates about issues regarding the practices of HC. Regarding this, the study reviewed institutional documents of Indonesia's legislations on heritage conservation, research articles, and international conventions of HC. These sources provided insight into the official heritage. In addition, newspapers and online media were also used to elaborate social context about the topic (Brennen, 2012; Corbetta, 2003).

- Second stage: the analysis of unofficial heritage. The study was grounded in the notion that people's perceptions are essential to understand the cultural value of heritage as suggested by Vecco (2010). The everyday meaning of heritage was captured from general publics' opinion about the historical-cultural values of heritage and particularly traditional thought or spirituality associated with traditional urban fabrics. The interviews involved 24 general public participants recruited from public spaces surrounding the heritage sites.

- Last stage. In this phase, findings from the previous steps were compared to reveal the connection and disconnection between official and unofficial heritage.

\section{THE REPRESENTATION OF OFFICIAL HERITAGE}

The development of official approach of HC can be traced back in the colonial period. Heritage protection has been recognised in Indonesia since the colonial period. In 1885, the colonial government inaugurated an organisation working on historical and archaeological research in Indonesia (Tanudirjo, 2003). After Indonesia gained its independence in 1945 , the country still used the colonial legislation until the government ratified the Convention Concerning the Protection of the World Cultural 
and Natural Heritage (The Republic of Indonesia, 1989) and legislated Cultural Heritage Property Act number 5 in 1992 (Fitri et al., 2015). In 2010, the central government of Indonesia enacted Cultural Heritage Act number 11 that is currently applied. According to this regulation, cultural heritage $(\mathrm{CH})$ is the physical representation of cultural legacy in the form of objects, building, structure, sites, and areas (The Republic of Indonesia, 2010). At the local scale, the provincial government of Yogyakarta has ratified the national HC regulation through the provincial regulation to meet the local context of HC (The Provincial Government of Yogyakarta, 2012).

Both the national and Yogyakarta regulations concern purposes of HC such as protecting local culture, strengthening identity and supporting the economy (The Provincial Government of Yogyakarta, 2012; The Republic of Indonesia, 2010). The practice of HC usually uses government regulation to determine what best represents the historical and cultural past ( $\mathrm{Su}, 2018)$. In a city context, buildings and urban landscapes are of public interests and the object of HC policy (Mualam \& Alterman, 2018). The integration of $\mathrm{HC}$ and public policy reflects the government commitment to follow international conventions in adopting principles of heritage interpretation and presentation (ICOMOS, 2008). The policy safeguards the process by which heritage can be recognised widely and managed sustainably as cultural and economic resources.

Table 1. List of heritage objects located in Yogyakarta urban centre (Balai Pelestarian Cagar Budaya Yogyakarta, 2019; with necessary modification)

\begin{tabular}{|l|l|}
\hline Heritage objects & Physical forms \\
\hline Vredeburg fort & Colonial fort \\
\hline Kraton fort & Fort made by Yogyakarta court \\
\hline Gedung Agung & Colonial building formerly used as a colonial office \\
\hline Margamulya church & Religious building \\
\hline Kauman mosque & Religious building \\
\hline Klenteng Hok Tik Bio & Religious building \\
\hline SDN Ngupasan building & Colonial building used as a school \\
\hline KONI building & Colonial building used as an office \\
\hline Bank BNI 1946 building & Colonial building used as a bank office \\
\hline Post Office building & Colonial building used as a post office \\
\hline Bank Indonesia building & Colonial building used as a bank office \\
\hline $\begin{array}{l}\text { Kraton complex and } \\
\text { Tamansari }\end{array}$ & The palace complex of Yogyakarta \\
\hline Pakualaman museum & A section of Yogyakarta palace used as a museum \\
\hline Panggung Krapyak & $\begin{array}{l}\text { An element of philosophical axis in the form of a } \\
\text { monument located to the south of Kraton. }\end{array}$ \\
\hline Tugu & $\begin{array}{l}\text { An element of philosophical axis in the form of a } \\
\text { monument located to the north of Kraton. }\end{array}$ \\
\hline Beringharjo market & Traditional market located to the north of Kraton \\
\hline
\end{tabular}

Yogyakarta heritage is protected by the Cultural Heritage Act number 11/2010 and the Provincial Regulation of Daerah Istimewa Yogyakarta number 6/2012. The Bureau of Cultural Heritage Conservation (Balai Pelestarian Cagar Budaya/BPCB) lists 16 historic buildings located in the urban centre of Yogyakarta (Balai Pelestarian Cagar Budaya 
Yogyakarta, 2019). These objects are forts, religious buildings, palaces, monuments, and offices (see Table 1). All of these buildings were constructed in the $18^{\text {th }}$ and $19^{\text {th }}$ centuries.

The following photos show two examples of buildings protected by the current legislations. Figure 3 depicts Tamansari-located in Kraton (palace) complex.

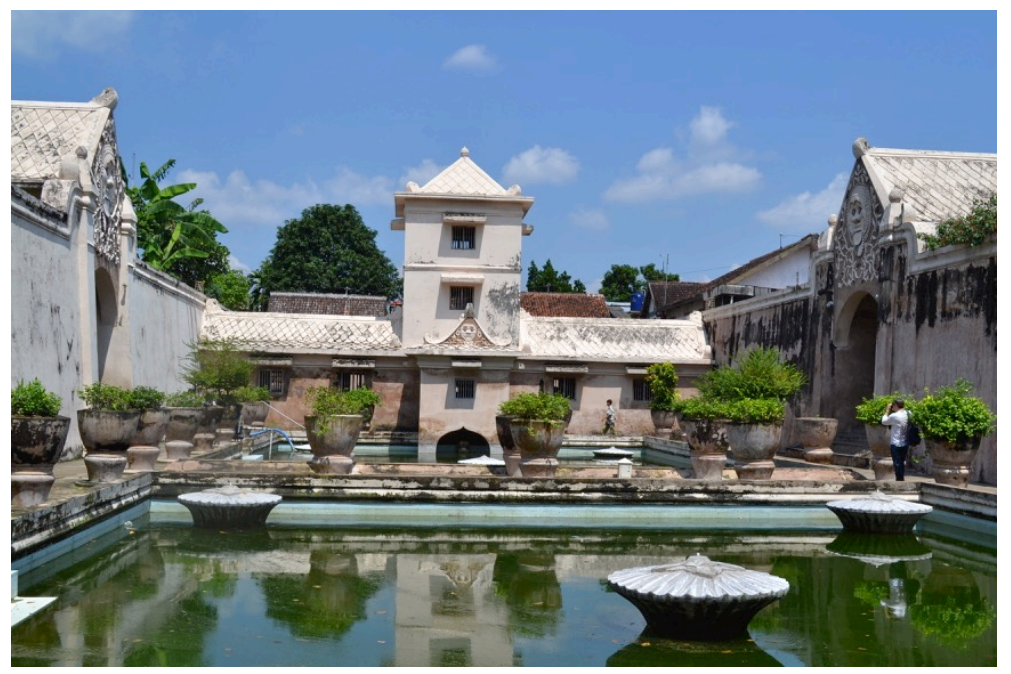

Figure 3. Tamansari or the Water Palace in Kraton complex. (The first author, 2019)

Tamansari was built in 1765 and designed by Tumenggung Mangundipura and Demang Tegis (Wardani et al., 2013). This site represents traditional architecture and court antiquity. Figure 4 below presents a sample of colonial building with Indische style. This building was built in 1879 and designed by two Dutch architects-Eduard Cuypers and Marius Hulswit (Kurniawan, 2017). This building is one of a few heritage buildings in monumental scale located at the northern area of Kraton.

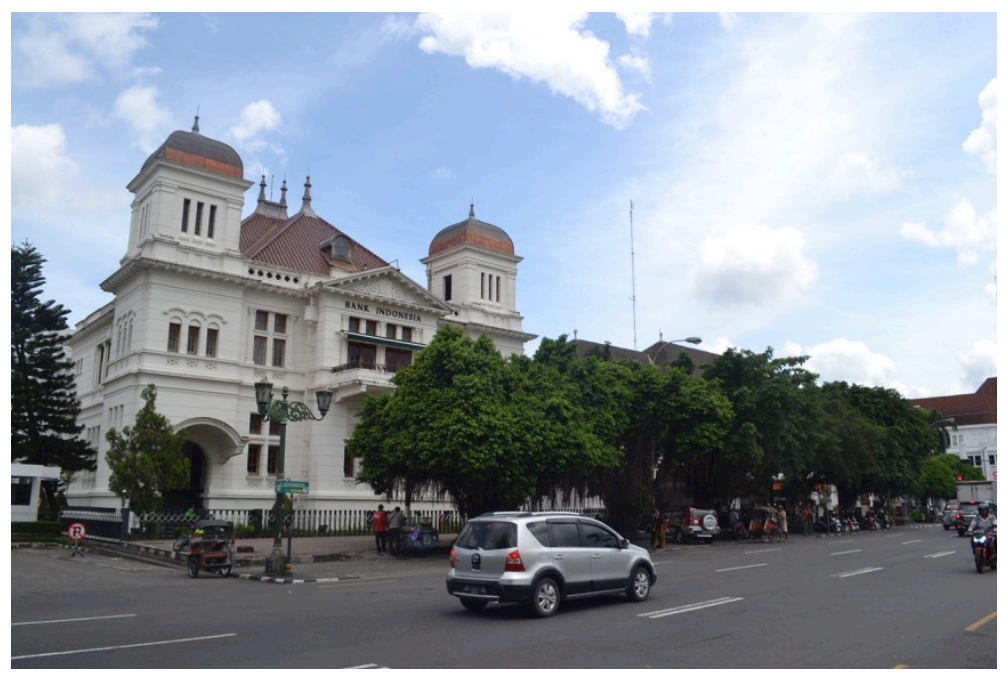

Figure 4. The Central Bank of Indonesia. (The first author, 2019)

The provincial government specifically protects philosophical axis representing the particularity of Yogyakarta heritage as mandated in chapter six of the Provincial Regulation of Cultural Heritage. The 
Rethinking the Heritage Value from Different Perspectives, Case Study in Yogyakarta

municipal government of Yogyakarta also includes cultural heritage in the current urban development plan by designating the area of philosophical axis as conservation and tourism zones (The Municipal Government of Yogyakarta, 2015). Figure 5 depicts the zoning map of Yogyakarta. On this map, the core of Kraton complex (the palace), Vredeburg fort, and Gedung Agung building are designated as heritage conservation zones (coloured in solid purple). The map also demonstrates the northern area of Kraton as a commercial area supporting the heritage tourism.

Figure 5. The current zoning map expresses heritage sites as conservation and tourism areas. (The Municipal Government of Yogyakarta, 2015; with necessary modification)

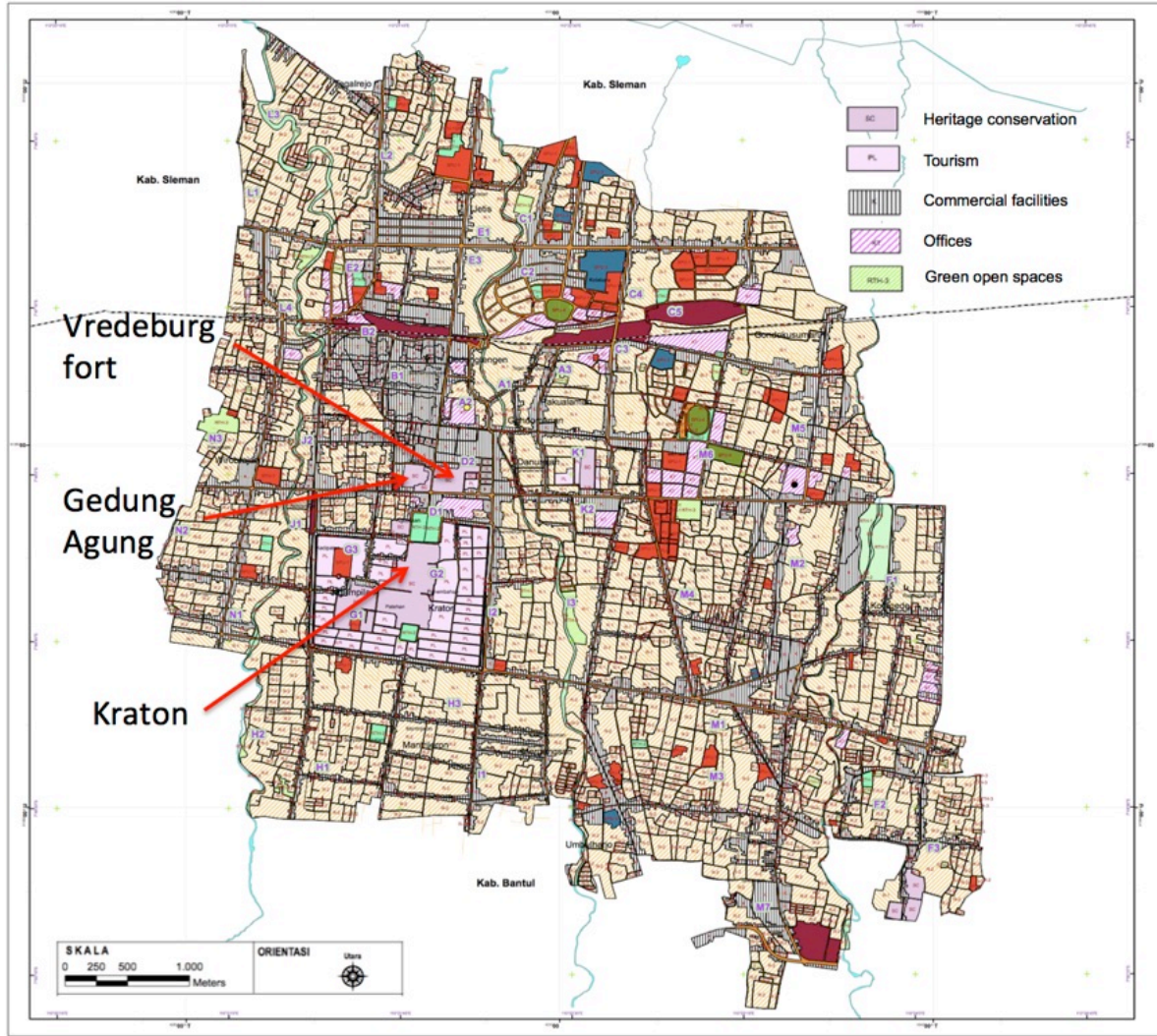

506

Heritage tourism is one of the government's priorities (Giyanto, 2015). The policy is initiated by the registration and protection of heritage. The action plan of Yogyakarta historic city continues the protection by integrating $\mathrm{HC}$ in tourism industry to foster local economy (The Municipal Government of Yogyakarta, 2012). In this case, tourism is a form of commonly implemented 'intentional activity' following heritage conservation (Graham et al., 2000). The implementation of heritage tourism reflects the government's intentions to benefit from the economic value of heritage (Vargas, 2018). This strategy is essential to provide finances for conservation as well as encourage local entrepreneurs and the subjects of $\mathrm{HC}$ to keep participating in conservation. 


\section{SOME ISSUES REGARDING HERITAGE CONSERVATION}

HC is primarily directed to enhance the living quality in urban settlements as a part of sustainable development agenda (The United Nations, n.d.). This practice requires measures regarding stakeholders' collaboration and responsible tourism to secure the heritage authenticity and equity in $\mathrm{HC}$ practices (World Heritage Committee, 2012, 2015). Particularly in urban area, HC becomes an essential sector due to its economic and cultural potentials. Nevertheless, this potential is coincident with a threat caused by unmanaged urbanisation as suggested by UNESCO (2011) and the Indonesia heritage board (Balai Pelestarian Pusaka Indonesia, 2013).

As explained earlier, the regulation of $\mathrm{HC}$ is followed up with urban planning and tourism policies. Kraton complex has been designated as conservation zone that allows tourism. In addition, Malioboro Street (the northern part of philosophical axis) and Kotabaru district is appointed as a commercial zone. Kotabaru district is a historic area located to the east of philosophical axis. Figure 6 depicts the current situation on Malioboro Street with many commercial buildings. The situation expresses a general issue of HC in Yogyakarta.

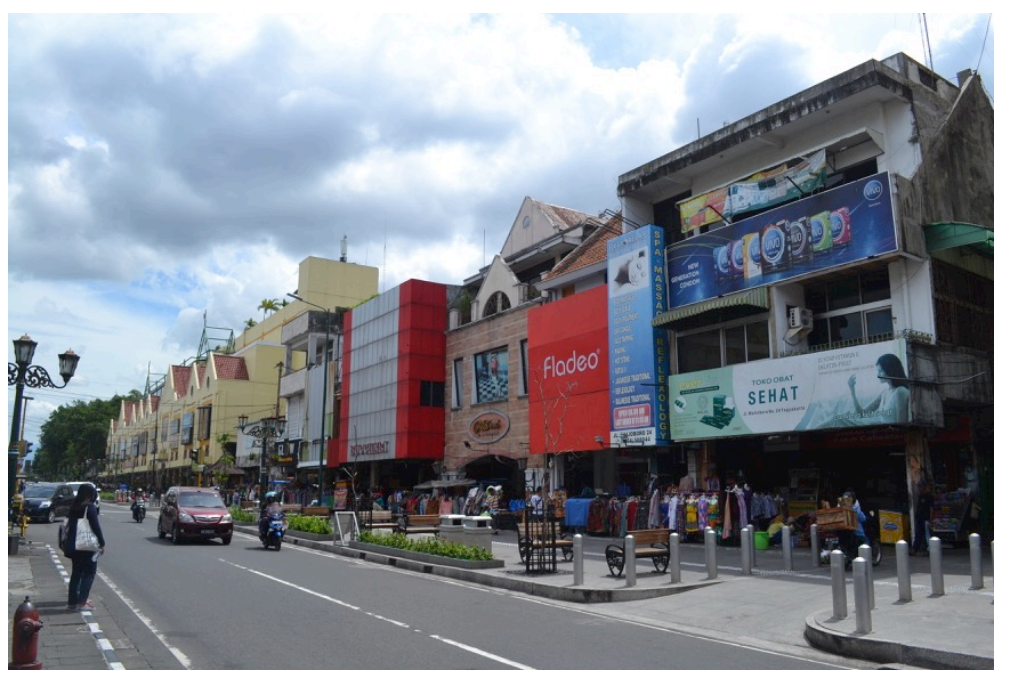

It is not surprising that the current image of Yogyakarta as a heritage and tourism city attracts many people and investments. Unfortunately, this situation leads to a paradox that the attraction of heritage can, in turn, become a problem to HC. Tourism has encouraged hotels to overload the Yogyakarta region in 2016 (Maharani, 2016). There are also other problems such as the spoiled water quality due to the massive hotel development (Ferish, 2016) and the destruction of old buildings (Murti \& Wijaya, 2013). The look of modern and commercial facilities gradually dominates urban spaces. Figure 6 obviously expresses this condition.

The urbanisation also influences people's perception about the particularity of Yogyakarta. An interview participant argued that Yogyakarta had lost its singularity. This person said:
Figure 6. The current situation at Malioboro Street. (The first author, 2019) 
"There are so many tall and modern buildings that make Yogyakarta looks the same as other cities. We can no longer promote the uniqueness of this city".

Other participants criticised the current situation by asserting that the heritage sites had become a mere tourism object without any appreciation for historic and symbolic values. Therefore, in the perspective of research participants, Yogyakarta was no longer recognised as a traditional city, but a metropolis, capitalised, and secularised city. Concerning this, scholars have warned an issue as the simplification of cultural and historical meanings into economic consumption (de Noronha Vaz et al., 2012; L. Smith, 2006; Wall \& Black, 2004). It seems that the current practice of official heritage is incapable of preventing this problem.

These opinions suggest that there is a shift of image of Yogyakarta, from the past romanticism promoted by HC policy to the current reality of urbanisation. Although the individual heritage buildings are still present, the urban space has started to lose its association with history and traditional philosophy.

\section{THE REPRESENTATION OF UNOFFICIAL HERITAGE}

This study implemented in-depth interviews in investigating the unofficial heritage. The participants were asked to express their opinions about colonial and traditional heritage. As a result, the study found meanings associated with the colonisation and traditional philosophy.

\section{Meanings Associated with the Colonisation}

The first meaning is associated with history. Research participants mentioned historic buildings and monuments as cagar budaya (cultural heritage). The government also uses the same term to indicate the heritage. The use of this term expresses people's awareness about HC and government's involvement in the practices. In this sense, the conservation has contributed to public recognition of the physical representations of heritage and the meanings.

Heritage connects Yogyakarta society to collective memories about colonisation and the war of independence around 1945. The participants admitted that colonial buildings recalled memories about the past tragedy and evoked the spirit of nationalism. Regarding this, a participant argued that:

"It is true that the colonial buildings are Dutch heritage, but the buildings also reflect Indonesian fighting spirit against colonisation".

Another participant suggested:

"Thanks to the current government (through HC policy), so we can remember the history. We should conserve (the heritage) and continue to prolong the independence". 
These statements express the connection between heritage, collective memory, and nationalism. The collective memory is primarily about the polarity between the colonials and the colonised society by creating the image of native society as primitive savage that needs control from the more advanced society as argued by Said (1979). This political situation is particularly expressed by the presence of Dutch military area the early industrialisation in Yogyakarta (Siregar, 2019).

The colonisation has situated the Indonesians in the same experience of the past tragedy or 'historical identity' as argued by Smith (2012). However, the historical narrative has not ended. Instead, it evolves into a consensus about what should be done in the present and the futureprolonging the independence and developing the society. In other words, the heritage sites evolve a narrative from the tragic colonisation into the present and future imagery of Yogyakarta society.

\section{Meanings Associated with Traditional Philosophy}

The second meaning reflects traditional philosophy. Herusatoto (2001) argues that particularly in Javanese society, like Yogyakarta, the symbolism is essential to the internalisation of traditional value in the society.

In each interview, the participants were asked to explain the meanings of traditional urban fabrics according to their perspective. Two questions were asked: "what are the meanings of the traditional sites for you and Yogyakarta society?" and "what makes you and the society believe (as a part of local religion) and appreciate the meanings?" These questions stimulated in-depth conversations about the topic.

Table 2. Themes and meanings from the first question

\begin{tabular}{|c|c|c|}
\hline Themes & Representations & Perceived meanings \\
\hline Traditional city & $\begin{array}{l}\text { Traditional urban fabrics in } \\
\text { general forming the } \\
\text { philosophical axis and } \\
\text { Catursagatra. }\end{array}$ & $\begin{array}{l}\text { - Lofty value (nilai-nilai luhur) of } \\
\text { Yogyakarta urban morphology } \\
\text { - A belief (kepercayaan) of } \\
\text { people in Yogyakarta }\end{array}$ \\
\hline Philosophical axis & $\begin{array}{l}\text { An urban form } \\
\text { configuration comprised of } \\
\text { Tugu monument, Kraton } \\
\text { (the palace), and Panggung } \\
\text { Krapyak monument }\end{array}$ & $\begin{array}{l}\text { - Symbolic relationships } \\
\text { between Yogyakarta and } \\
\text { geographical features } \\
\text { surrounding the city } \\
\text { - Symbolising harmony in three } \\
\text { relationships: between human } \\
\text { and God (orientation to Mount } \\
\text { Merapi or the north), the social } \\
\text { relationship among humans } \\
\text { (orientation to Kraton), and the } \\
\text { relationship between human } \\
\text { and nature (orientation to } \\
\text { South Ocean or the south) }\end{array}$ \\
\hline Catursagatra & $\begin{array}{l}\text { An urban form } \\
\text { configuration comprising } \\
\text { Kraton, Alun-Alun, the Great } \\
\text { Mosque, and Beringharjo } \\
\text { market }\end{array}$ & $\begin{array}{l}\text { Symbolising kinship among } \\
\text { people and harmony in social life }\end{array}$ \\
\hline
\end{tabular}


The analysis revealed five themes: traditional urban form, philosophical axis, Catursagatra, sustaining traditional values and living museum. Table 2 and Table 3 summarise the interview findings.

Regarding the first interview question, the participants mentioned some representations of traditional symbols in Yogyakarta's urban formphilosophical axis and Catursagatra (see Table 2). The current components of these traditional models of urban form are the same as the ones developed in the past.

The majority of participants argued that the traditional urban form of Yogyakarta symbolises the sublime value of local wisdom (nilai luhur). A few participants emphasised this opinion by asserting that this value corresponds to a belief in Yogyakarta. It was evident that this participant projected Yogyakarta's cosmology on to the urban form, i.e. the philosophical axis and Catursagatra.

The second question revealed opinions about the motivations behind the admiration for the traditional philosophy (see Table 3). Participants argued that heritage is more than a historical commemoration. They suggested that the values provided an ethical standard for the current civilisation.

Table 3. Themes and meanings from the second question

\begin{tabular}{|l|l|}
\hline Themes & Perceived meanings \\
\hline Sustaining traditional & $\begin{array}{l}\text { - Transmitting traditional values or norms and wisdom } \\
\text { through generations } \\
\text { values }\end{array}$ \\
& $\begin{array}{l}\text { Building personal character following traditional } \\
\text { values }\end{array}$ \\
\hline Living museum & but also the society that still prolonged its tradition. \\
\hline
\end{tabular}

As suggested by Herusatoto (2001) and Roqib (2007), Javanese tradition aims at building personal character through spirituality and morality. Regarding this, a participant said:

"I am happy with the presence of mystical values in Yogyakarta (as represented by the traditional philosophy) because it is a part of the society. I do not see myself as a Christian or Catholic. Rather, I prefer to admit everyone as a human with a common cultural background (the Javanese), history, and communication style (language)".

The traditional urban fabrics symbolise local wisdom, which remind people to live in harmony, equality, and peace. The majority of participants argued that this kind of interaction is the character of Javanese people who expresses their ethnic identity. It is how an individual could be recognised as a Javanese. Su (2018) uses the term 'authentic self', which is associated to this kind of identity. This identity allows a person to claim themself as a true part of a social group. This finding suggests that the traditional urban fabrics, philosophical meanings, and social character building are integral to Yogyakarta's 
culture. It is a responsibility of each society member to preserve the identity by participating in $\mathrm{HC}$ and prolonging the tradition. Consequently, the blending between traditional urban fabrics and the character of society makes the historic area as a living heritage. It is a place where heritage is manifested not only through the buildings, but also the people who prolong traditional philosophy from the ancestors.

\section{THE RELATIONSHIP BETWEEN OFFICIAL AND UNOFFICIAL HERITAGE IN YOGYAKARTA}

There is a connection between the official and unofficial approaches in the construction of heritage value. To a certain extent, the official approach of HC has supported the unofficial heritage by conserving prominent historic buildings that allow observers to recognise the overall history and local culture in Yogyakarta. Then the deeper senses of heritage value, such as nationalism and pride, are formed among the people.

The study found that the official heritage connects with unofficial heritage in three forms. Firstly, the official heritage contributes to the creation of post-colonial meanings. The study found that research participants are still aware of tragedies associated with the colonisation and independence war. However, the memory does not stop at the tragedies, but evolves into the current interpretation of freedomnationalism and a spirit to sustain the independence. Secondly, the heritage policy conserves traditional symbols essential to local belief and wisdom. The implementation of this policy reflects a practice of using local belief to connect the city and its citizens with the traditional 'past' as also suggested by Zhu (2018). It is a primary contribution of HC to locality, since there is no other city in Indonesia designed in a traditional cosmology similar to Yogyakarta (Aditya, 2017). In the local context, HC policy helps Yogyakarta society to prolong their tradition. Thirdly, the overall HC develops pride in Yogyakarta cultural uniqueness. The government makes effort to educate citizens about historical and cultural significances. As a result, the research participants associated the term cagar budaya with historic buildings expressing their positive attitude to the current HC policy. The increase of public's appreciation of heritage in turn encourages the society to develop collective awareness and support $\mathrm{HC}$ as suggested by Monteiro, Painho, \& Vaz (2015).

The study also found a disconnection between the two approaches of HC. The aforementioned issues express this disconnection. This problem was evident through the increase of capitalist and secular values in the city as perceived by the participants. The city begins to lose its historical and philosophical meanings. The problem reflects a conflict between HC and economic activity that should be well managed by the local government. Although the official heritage does not intend to cause the problem, unfortunately, the current paradigm of official heritage allows heritage commodification to introduce the secular and universal values. 
The uncontrolled economic activity jeopardises the heritage value through the introduction of modern and commercial expressions as a competitor for cultural and historical values. Then a question rises about how $\mathrm{HC}$ and the degradation of heritage value can coincidently happen? The official approach of HC is characterised by the protection of individual historic buildings as shown in Table 1. Research participants still recognised each historic building from its appearance, along with the values. The research participants also used their perception to connect the value of a historic building with its surrounding. In this regards, the visuals of modernity strikingly defeated the heritage value of individual historic buildings. The same phenomenon is also evidenced in the study of Najd et al. (2015). They suggest that the surroundings have a major contribution to people's perception of heritage. The historic buildings are situated side by side with modern and commercial facilities. In a situation where commercial facilities dominate the urban space, the sense of history can be easily distorted by modernity. This case reflects a gap between experts and non-experts in the interpretation of heritage as asserted by Fredheim \& Khalaf (2016). Especially in an urban area, the heritage value in terms of authenticity as described in Nara Document (ICOMOS, 2004) is delicate because the surroundings of heritage site sensitively affect people's perception. In this case, the government should have a better control on urban development that can influence the physical character around the heritage sites.

The practices of official and unofficial heritage approaches should be well combined. The official heritage provides a systematic and legal way of HC. By using this approach, the government of Yogyakarta has a capacity to control urban development and physical character around the heritage sites. This act makes heritage available as a long-term economic resource. Regarding this, the authority has a key role to manage the interpretation and presentation of heritage as suggested by ICOMOS (2008). The unofficial heritage can support the practice of official heritage by incorporating general public in HC. The practice of unofficial heritage contributes to social benefits in terms of social bond and character building. Heritage gives a direct effect on people's comprehension of tradition and collective memories. In addition, the practice of unofficial heritage is sensitive to the distortion of heritage value that is mostly caused by urban development and heritage commodification. In this case, the authority as the city regulator should pay attention to citizens' perception of the heritage values and use this perception to notice the value distortion. There is a need for local community and NGO to get involved in HC especially in coping with institutional difficulties of government agencies as argued by Hung (2015). Through this collaboration, the government and society will have the capability to diminish the negative effect of heritage commodification and urban development. 


\section{CONCLUSIONS AND RECOMMENDATIONS}

The study demonstrates that official and unofficial approaches of heritage are inseparable. This study has provided evidence that a problem is present in the form of massive heritage tourism that shifts the traditional meanings of Yogyakarta. This becomes the rationale for why the government through official heritage needs to protect the singularity of Yogyakarta by also paying attention to meanings perceived by the citizens.

The unofficial heritage is primarily characterised by symbolic values expressing nationalism and traditional philosophy that present as the outcome of official heritage. The meanings strengthen social attachment to the city and support the citizen's character building as guided by the traditional philosophy. This situation represents the locality of Yogyakarta. In this case, there is a connection between the official and unofficial approaches of heritage regarding historical and cultural values.

The comprehension of unofficial heritage contributes to an academic discourse associated with the notion of heritage value. The unofficial approach of heritage has a potential for unfolding the perceived meanings of heritage. The study found that the meanings are closely related to the physical condition of historic area in terms of the presence of modern facilities and activities. Therefore, this approach can be used to evaluate the extent to which urban development influence heritage and the values that is the notable finding of this study.

The pragmatic contribution of this study concerns the government involvement in controlling urban development around heritage buildings. HC is not only about the protection of individual heritage buildings, but also the creation of appropriate environment around the heritage sites. In the case of Yogyakarta, the better urban development plan and monitoring are needed so that the degradation of heritage value can be avoided. Regarding this, the perception of general public provides an analytical tool of assessing the value change.

The central and municipal governments, through official heritage, provide legal standing and regular programs for HC. Through this way, the two-way cooperation between government and citizens can be maintained to prolong sustainability and a balance between the historical-cultural and economic aspects of the city.

\section{ACKNOWLEDGEMENTS}

The first author would like to express his appreciation to Dr. Mirko Guaralda and Dr. Rajjan Man Chitrakar from School of Design, Queensland University of Technology, for their supports.

\section{CONFLICT OF INTERESTS}

The authors declared that there was no conflict of interest. 
Rethinking the Heritage Value from Different Perspectives, Case Study in Yogyakarta

\section{FINANCIAL DISCLOSURE}

The authors declared that this study has received no financial support.

\section{ETHICS COMMITTEE APPROVAL}

Ethics committee approval was not required for this article.

\section{LEGAL PUBLIC/PRIVATE PERMISSIONS}

In this research, the necessary permissions were obtained from the relevant participants during the in-depth interview.

\section{REFERENCES}

Aditya, I. (2017). Yogyakarta the city of philosophy. https://krjogja.com/web/news/read/30098/Yogyakarta_City_of_Philos ophy

Alexander, H. (2015). Yogyakarta, Kota Pusat Perbelanjaan. http://properti.kompas.com/read/2015/11/03/124405221/Yogyakart a.Kota.Pusat.Belanja?page $=$ all

Balai Pelestarian Cagar Budaya Yogyakarta. (2019). The Potential of Cultural Heritage Object in Yogyakarta, BPCB Yogyakarta. https://kebudayaan.kemdikbud.go.id/bpcbyogyakarta/publikasi/

Balai Pelestarian Pusaka Indonesia. (2013). Piagam Pelestarian Kota Pusaka Indonesia. BPPI.

Brennen, B. (2012). Qualitative research methods for media studies. Routledge.

Byrne, D. R. (2008). Heritage as social action. In G. Fairclough, R. Harrison, J. Schofield, \& J. H. Jameson (Eds.). The heritage reader (p. 149). Routledge.

Corbetta, P. (2003). Social research: theory, methods and techniques. Sage.

de Noronha Vaz, E., Cabral, P., Caetano, M., Nijkamp, P., \& Painho, M. (2012). Urban heritage endangerment at the interface of future cities and past heritage: A spatial vulnerability assessment, Habitat International, 36(2), 287-294.

Ferish, N. (2016). Krisis air dan konflik infrastruktur komersil di Yogya makin memprihatinkan. https://www.kompasiana.com/nelsonferish/5 6f98d9084afbd70078bd3d1/krisis-air-dan-konflik-infrastrukturkomersil-di-yogya-makin-memprihatinkan

Fitri, I., Ahmad, Y., \& Ahmad, F. (2015). Conservation of tangible cultural heritage in Indonesia: A review current national criteria for assessing heritage value, Procedia-Social and Behavioral Sciences, 184, 71-78.

Fredheim, L. H., \& Khalaf, M. (2016). The significance of values: Heritage value typologies re-examined, International Journal of Heritage Studies, 1-17.

Giyanto, A. (2015). Tujuh Prioritas Pembangunan Kota Yogyakarta 2016. http://jogjadaily.com/2015/03/musrenbang-2016-kota-yogyakartapusat-jasa-berwawasan-lingkungan-dan-ekonomi-kerakyatan/ 
Graham, B., Ashworth, G. J., \& Tunbridge, J. E. (2000). A geography of heritage: Power, culture, and economy. Arnold; Oxford University Press.

Handinoto. (2015). Perkembangan kota di Jawa abad XVIII sampai dengan pertengahan abad XX. Ombak Publisher.

Harrison, R. (2013). Heritage: Critical approaches. Routledge, Taylor and Francis Group.

Herliana, E. T., Hanan, H., \& Kusuma, H. E. (2019). Significant factors of sense of place that makes Jeron Beteng Yogyakarta sustainable as a historical place, Advances in Engineering Research. https://doi.org/https://doi.org/10.2991/senvar-18.2019.21

Herusatoto, B. (2001). Simbolisme dalam budaya Jawa. Hanindita Graha Widia.

Hung, H. (2015). Governance of built-heritage in a restrictive political system: The involvement of non-governmental stakeholders, Habitat International, 50, 65-72.

ICOMOS. (2004). International charters for conservation and restoration. International Secretariat of ICOMOS.

ICOMOS. (2008). The ICOMOC charter for the interpretation and presentation of cultural heritage sites. ICOMOS.

Jokilehto, J. (2006). Considerations on authenticity and integrity in world heritage context. City \& Time, 2(1), 1.

Juodinyte-Kuznetsova, K. (2011). Architectural space and Greimassian semiotics, Socialiniu Mokslu Studijos, 3(4).

Karsono, B., \& Wahid, J. (2008). Imaginary axis as a basic morphology in the city of Yogyakarta-Indonesia. 2nd International Conference on Build Environment in Developing Countries.

Kurniawan, B. (2017). Gedung BI, salah satu bangunan bergaya Indis di Yogyakarta. https://news.detik.com/berita-jawa-tengah/d-

3584631/gedung-bi-salah-satu-bangunan-bergaya-indis-di-yogyakarta

Kusumaputra, R. A. (2010). Diprotes, bangunan tua di Jogja dijadikan resto cepat saji. http://properti.kompas.com/read/2010/06/16/17240549/Diprotes..B angunan.Tua.di.Jogja.Dijadikan.Resto.Cepat.Saji

Loulanski, T. (2006). Revising the concept for cultural heritage: the argument for a functional approach, International Journal of Cultural Property, 13(2), 207.

Luthfi, Nazir, Tohari, Winda, \& Tristiawan. (2014). Keistimewaan Yogyakarta yang diingat dan yang dilupakan. Ombak Publisher.

Maharani, S. (2016). Yogyakarta marak pembangunan hotel. https://m.tempo.co/read/news/2016/01/23/090738700/yogyakartamarak-pembangunan-hotel-ini-kritik-ekonom-ugm

Malpas, J. (2008). New media, cultural heritage and the sense of place: Mapping the conceptual ground, International Journal of Heritage Studies, 14(3), 197-209.

Monteiro, V., Painho, M., \& Vaz, E. (2015). Is the heritage really important? A theoretical framework for heritage reputation using 
Rethinking the Heritage Value from Different Perspectives, Case Study in Yogyakarta

citizen sensing, Habitat International, 45, 156-162.

Mualam, N., \& Alterman, R. (2018). Looking into the 'black box' of heritage protection: Analysis of conservation area disputes in London through the eyes of planning inspectors, International Journal of Heritage Studies, 24(6), 599-618.

Murti, C., \& Wijaya, H. B. (2013). Pengaruh kegiatan komersial terhadap fungsi bangunan bersejarah di koridor jalan Malioboro Yogyakarta, Jurnal Teknik PWK, 2(1), 60-75.

Najd, M. D., Ismail, N. A., Maulan, S., Yunos, M. Y. M., \& Niya, M. D. (2015). Visual preference dimensions of historic urban areas: The determinants for urban heritage conservation, Habitat International, 49, 115-125.

Ritchie, J., Lewis, J., Nicholls, C. M., \& Ormston, R. (2013). Qualitative research practice: A guide for social science students and researchers. Sage Publications.

Roqib, M. (2007). Harmoni dalam budaya Jawa. Pustaka Pelajar.

Said, E. W. (1979). Orientalism. Vintage Books.

Schorch, P. (2014). Cultural feelings and the making of meaning, International Journal of Heritage Studies, 20(1), 22-35.

Shepherd, R. (2002). Commodification, culture and tourism, Tourist Studies, 2(2), 183-201.

Siregar, J. P. (2019). The ideological meanings of heritage: The conflicting symbols in Yogyakarta, Indonesia. DIMENSI Uournal of Architecture and Built Environment), 45(2), 121-132.

Smith, A. D. (2012). Towards a global culture? Theory, culture and society. In M. B. Steger (Ed.), Globalization and Culture (Vol. 1, pp. 349369). Edward Elgar Publishing Limited.

Smith, L. (2006). Uses of heritage. Routledge.

$\mathrm{Su}, \mathrm{J}$. (2018). Conceptualising the subjective authenticity of intangible cultural heritage, International Journal of Heritage Studies, 24(9), 919937.

Suryanto, Ahmad, D., \& Sudaryono. (2015). Aspek budaya dalam keistimewaan tata ruang Kota Yogyakarta, Jurnal Perencanaan Wilayah Dan Kota, 26(3), 230-252.

Tanudirjo, D. A. (2003). Warisan budaya untuk semua: Arah kebijakan pengelola warisan budaya Indonesia di masa mendatang. Kongres Kebudayaan V, 19-23.

The Municipal Government of Yogyakarta. (2012). Heritage city action plan of Yogyakarta.

The Municipal Government of Yogyakarta. (2015). Municipal Regulation number 1 /2015: The detailed spatial plan and zoning regulation.

The Provincial Government of Yogyakarta. (2012). Provincial Regulation number 6 / 2012: The conservation of cultural heritage.

The Republic of Indonesia. (1989). Presidential Decree number 26 / 1989: Pengesahan convention concerning the protection of the world cultural and natural heritage. 
The Republic of Indonesia. (2010). Act number 11 / 2010: Cultural heritage.

The United Nations. (n.d.). Transforming our world: The 2030 agenda for sustainable development. https://sustainabledevelopment.un.org/post2015/transformingourwor ld

Tweed, C., \& Sutherland, M. (2007). Built cultural heritage and sustainable urban development, Landscape and Urban Planning, 83(1), 62-69.

UNESCO. (2011). Recommendation on the historic urban landscape.

UNESCO. (2017). Historical city centre of Yogyakarta. http://whc.unesco.org/en/tentativelists/6206/

Vargas, A. (2018). The tourism and local development in world heritage context: The case of the Mayan site of Palenque, Mexico. International Journal of Heritage Studies, 24(9), 984-997.

Vecco, M. (2010). A definition of cultural heritage: From the tangible to the intangible, Journal of Cultural Heritage, 11(3), 321-324.

Veenendaal, A. M., \& Knaap, P. D. G. (2015). Building modernity: Indische architecture and colonial autonomy, 1920-1940. In Faculty of Humanities: Vol. Bachelor. Utrecht University.

Wall, G., \& Black, H. (2004). Global heritage and local problems: Some examples from Indonesia, Current Issues in Tourism, 7(4\&5), 436-439.

Wardani, L. K., Soedarsono, R. M., Haryono, T., \& Suryo, D. (2013). City heritage Of Mataram Islamic Kingdom In Indonesia. Case study of Yogyakarta Palace, The International Journal of Social Sciences, 9(1), 104-118.

World Heritage Committee. (2012). World heritage tourism programme. UNESCO.

World Heritage Committee. (2015). World heritage and sustainable development. UNESCO.

Yunus, H. S. (1991). The evolving urban planning: The case of the city of Yogyakarta, Indonesian Journal of Geography, 21(61), 1-14.

Zhu, Y. (2018). Uses of the past: Negotiating heritage in Xi'an, International Journal of Heritage Studies, 24(2), 181-192.

\section{Resume}

Dr Johannes Parlindungan has received his Ph.D. in the field of urban design from Queensland University of Technology, Australia. His main concerns are thematic urban design, public space and urban morphology relating to the dynamics caused by urbanisation and societal changes. He currently works in Department of Regional and Urban Planning, Universitas Brawijaya, Indonesia.

Dr Wara Indira Rukmi gained her doctoral degree from Gadjah Mada University, Indonesia. She has involved in many researches relating to urban settlement, traditional settlement and heritage. Wara is currently a lecturer in Department of Regional and Urban Planning, Universitas Brawijaya, Indonesia. 